\title{
Nutritional Utilization in Malagueña Dairy Goats Differing in Genotypes for the Content of $\alpha_{S 1}$-Casein in Milk
}

\author{
G. De la Torre, ${ }^{*}$ J. M. Serradilla, $\dagger$ F. Gil Extremera, ${ }^{*}$ and M. R. Sanz Sampelayo*1 \\ ${ }^{*}$ Consejo Superior de Investigaciones Científicas, Estación Experimental del Zaidín, Unidad de Nutrición Animal, Profesor Albareda 1, \\ 18008 Granada, Spain \\ †Departamento de Producción Animal, ETSIAYM, Universidad de Córdoba, 14071 Córdoba, Spain
}

\begin{abstract}
A study was carried out with 20 goats of the Malagueña breed, half with a high (HG) and half with a low (LG) genetic capability for $\alpha_{\mathrm{S} 1}$-casein (AS1-CN) synthesis, to determine whether the 2 different genotypes (that cause differences in goat milk composition) are related to differences in nutritional feed utilization. Among the $10 \mathrm{HG}$ goats, 7 had $\mathrm{BB}$ and 3 had $\mathrm{AB}$ genotypes for $A S 1$ $C N$, whereas there were $7 \mathrm{EF}$ and $3 \mathrm{FF}$ genotypes in the $10 \mathrm{LG}$ goats. The goats were fed diets differing in crude protein content (13.6 vs. $17.7 \%$ dry matter for diets 1 and 2, respectively). For each genotype group, a balance trial was conducted with each of the 2 diets in a 2-period balanced changeover designed with half the animals consuming diet 1 and the other half diet 2 , determining individual feed intake and the utilization of $\mathrm{N}$ and energy in the diets. Greater voluntary feed intake on a metabolic body weight basis among the HG goats was identified as the first possible cause of their milk production. The HG goats also had a greater level of feed utilization, on a metabolic body weight basis, for $\mathrm{N}$ and energy intake. Greater ratios of $\mathrm{N}$ balance/ digestible $\mathrm{N}$, milk protein $\mathrm{N} /$ digestible $\mathrm{N}$, milk energy/ digestible energy, and milk energy/ME were found for HG goats compared with LG. These effects appear to be dependent on the level of protein in the diet, indicating interactive effects. The greater $\mathrm{N}$ and energy utilization of $H G$ versus $L G$ goats may explain the differences in milk composition between the 2 genotype groups.
\end{abstract}

Key words: intake level, feed $\mathrm{N}$ and energy utilization, genotype for $\alpha_{\mathrm{S} 1}$-casein, lactating goat

\section{INTRODUCTION}

In goats, the gene for $\alpha_{\mathrm{S} 1}$-casein $(A S 1-C N)$ in milk has an unusually high degree of genetic polymorphism with 18 allele types (Sacchi et al., 2005) that have been stud-

Received April 12, 2007.

Accepted January 31, 2008.

${ }^{1}$ Corresponding author: rsanz@eez.csic.es ied intensively since the 1980s (Boulanger et al., 1984). Grosclaude et al. (1987) analyzed the effects of the different alleles on the level of AS1-CN synthesis in Alpine and Saanen goats, and classified the 7 alleles into 4 groups: alleles A, B, and $\mathrm{C}$ with a high level of milk protein synthesis $(3.6 \mathrm{~g} / \mathrm{L})$, allele $\mathrm{E}$ with an intermediate level $(1.6 \mathrm{~g} / \mathrm{L})$, allele $\mathrm{F}$ with a low level $(0.6 \mathrm{~g} / \mathrm{L})$, and the null allele with $0.0 \mathrm{~g} / \mathrm{L}$. This same polymorphism has been observed in other European goat breeds as well as in Spanish goat breeds (Serradilla, 2002). The milk produced by goats with a high capacity for the synthesis of AS1-CN also tends to have greater concentrations of milk fat (Barbieri et al., 1995).

Among factors of nutritional feed utilization that determine the productive capacity of goats it has been reported that those with a high capacity for the synthesis of AS1-CN also have greater feed intake per metabolic BW (MBW) than those with a low capacity (Schmidely et al., 2002; De la Torre, 2006). Increased levels of energy intake, depending on the genetic merit of the animal, may lead to greater production of milk or greater concentration of protein and fat in the milk (Morand-Fehr et al., 2000; Boza, 2005). However, the differences in voluntary feed intake (VFI) do not seem to justify the differences found for the amount of protein, casein, and fat in the milk. Therefore, in addition to different intakes, there could be different nutritional utilization. Possible variations in protein requirements depending on the genotype associated with AS1-CN level in milk have still to be clarified. This paper describes results from a study with Malagueña dairy goats belonging to genotypes for either low or high capacity to synthesize AS1-CN in milk. The goats were fed 2 diets varying in protein contents, and the utilization of $\mathrm{N}$ and energy was determined for individual goats. The study of the utilization of $\mathrm{N}$ and energy in the diet was also undertaken to determine possible genetic $\times$ nutrition interactions in relation to genotype and protein content of the feed.

\section{MATERIALS AND METHODS}

\section{Experimental Design and Procedure}

Twenty Malagueña goats, from 4 herds, midway through their second, third, or fourth lactation were 
Table 1. Ingredient composition of the concentrates, chemical composition, and gross energy content of the concentrates, alfalfa hay, and barley straw

\begin{tabular}{|c|c|c|c|c|}
\hline \multirow[b]{2}{*}{ Item } & \multicolumn{2}{|c|}{ Concentrate $^{1}$} & & \\
\hline & D1 & D2 & & \\
\hline \multicolumn{5}{|l|}{ Ingredient, g/kg } \\
\hline Oats & 293 & 150 & & \\
\hline Corn & 390 & 75 & & \\
\hline Faba beans & 240 & 335 & & \\
\hline Bypass fat & 37 & - & & \\
\hline Corn gluten feed & - & 200 & & \\
\hline Cottonseed & - & 200 & & \\
\hline Mineral-vitamin supplement ${ }^{2}$ & 40 & 40 & & \\
\hline \multirow{2}{*}{$\begin{array}{l}\text { Chemical composition and gross energy content } \\
\text { DM, \% }\end{array}$} & \multicolumn{2}{|c|}{ Concentrate $^{1}$} & Alfalfa hay & Barley straw \\
\hline & 89.1 & 89.5 & 91.8 & 89.4 \\
\hline $\mathrm{OM}$ & 92.1 & 91.7 & 92.5 & 94.8 \\
\hline $\mathrm{CP}$ & 12.7 & 19.6 & 18.6 & 4.7 \\
\hline Fat & 6.8 & 6.5 & 10.0 & - \\
\hline $\mathrm{NDF}$ & 27.8 & 36.7 & 50.1 & 74.1 \\
\hline $\mathrm{ADF}$ & 8.6 & 16.3 & 3.7 & 4.6 \\
\hline Acid detergent lignin & 0.9 & 3.5 & 9.2 & 5.2 \\
\hline Gross energy, MJ/kg of DM & 18.6 & 18.5 & 19.0 & 18.2 \\
\hline
\end{tabular}

${ }^{1}$ Concentrate: $\mathrm{D} 1=13.6 \% \mathrm{CP}$ (DM basis); $\mathrm{D} 2=17.7 \% \mathrm{CP}(\mathrm{DM}$ basis $)$.

${ }^{2}$ Mineral-vitamin supplement composition (\% of DM): $5.8 \% \mathrm{Ca}, 17.1 \% \mathrm{P}, 25.0 \% \mathrm{NaCl}, 2.3 \% \mathrm{Fe}, 0.3 \% \mathrm{Cu}$, $1.5 \% \mathrm{Zn}, 1.2 \% \mathrm{Mn}, 3.0 \% \mathrm{Mg}, 0.05 \% \mathrm{Co}, 2.0 \%$ vitamin $\mathrm{A}, 0.13 \%$ vitamin $\mathrm{D}_{3}, 1.3 \%$ vitamin $\mathrm{E}, 0.8 \%$ nicotinic acid, $0.25 \%$ vitamin $\mathrm{B}_{1}, \mathrm{~B}_{2}$, and $\mathrm{B}_{12}$ (Musal Laboratory, Granada, Spain).

used. Ten of these animals had genotypes (7 BB and 3 $\mathrm{AB})$ associated with a high level of $\alpha_{\mathrm{S} 1}$-casein (AS1-CN) and total protein in milk (HG), and 10 had genotypes (7 EF and $3 \mathrm{FF}$ ) associated with a low level of AS1-CN and total protein in milk (LG). Each genotype group was made up of goats from all 4 herds to randomize the genetic backgrounds. Samples were taken from 300 animals for genotyping, which was performed following the protocol developed by Amills (1996). The animals were fed 2 diets differing in their CP content: $13.6 \%$ (diet 1 , D1) and $17.7 \%$ (diet 2, D2) of DM. The proportion of degradable protein in the rumen corresponding to the diets was very similar $(74.6 \pm 0.6 \%)$. An in vivo balance trial was conducted with the HG goats, using the 2 different diets in a 2-period balanced changeover design. Within each period, half of the animals consumed D1 and the other half consumed D2. The same procedure was used with the LG goats. Each goat received, at the same time and in separate containers, a daily ration consisting of $1.0 \mathrm{~kg}$ of forage and $1.0 \mathrm{~kg}$ of concentrate (Aguilera et al., 1990; NRC, 2007). The forage fraction of the diets consisted of long alfalfa hay (700 and $800 \mathrm{~g}$ per animal and day for D1 and D2, respectively) and barley straw (300 and $200 \mathrm{~g}$ per animal and day for D1 and D2, respectively). Table 1 shows the ingredient composition of the concentrates and the chemical composition and energy content of the concentrates and alfalfa hay and barley straw used. The total duration of each trial was $21 \mathrm{~d}$, the first $14 \mathrm{~d}$ of which were for adaptation and the last $7 \mathrm{~d}$ constituting the main trial period. During the main trial period the goats were housed individually in metabolism cages. The goats were hand milked daily at $0900 \mathrm{~h}$, once the orts from the previous day had been collected; daily rations were fed immediately thereafter. Water was available at all times. After milking, the goats were weighed on arrival at the laboratory and at the start and finish of the balance trials.

\section{Measurements and Analysis}

Daily samples of forage and concentrate together with samples of orts, feces, and urine were collected and maintained at $-20^{\circ} \mathrm{C}$ until analysis. Similarly, samples of milk with no added preservatives were stored at $-30^{\circ} \mathrm{C}$ until analysis. The $\mathrm{DM}$ and $\mathrm{N}$ contents were determined using fresh samples and all other analyses were carried out using dry samples. The DM content of the feedstuffs and orts were determined (AOAC, 2005), and that of the feces, urine, and milk were determined by lyophilization. The $\mathrm{N}$ content of the feedstuffs, orts, feces, urine, and milk were determined by the Kjeldahl method (AOAC, 2005). The protein $\mathrm{N}$ content of the milk samples was calculated as the difference between total N and NPN. Total $\mathrm{N}$ was determined from whole milk samples and NPN from a filtrate of whole milk after precipitation with $12 \%$ (wt/vol) TCA. Neutral detergent fiber, ADF, 
Table 2. Effect of type of $\operatorname{diet}^{1}$ and animal genotype ${ }^{2}$ on BW, nitrogen intake, and excretion

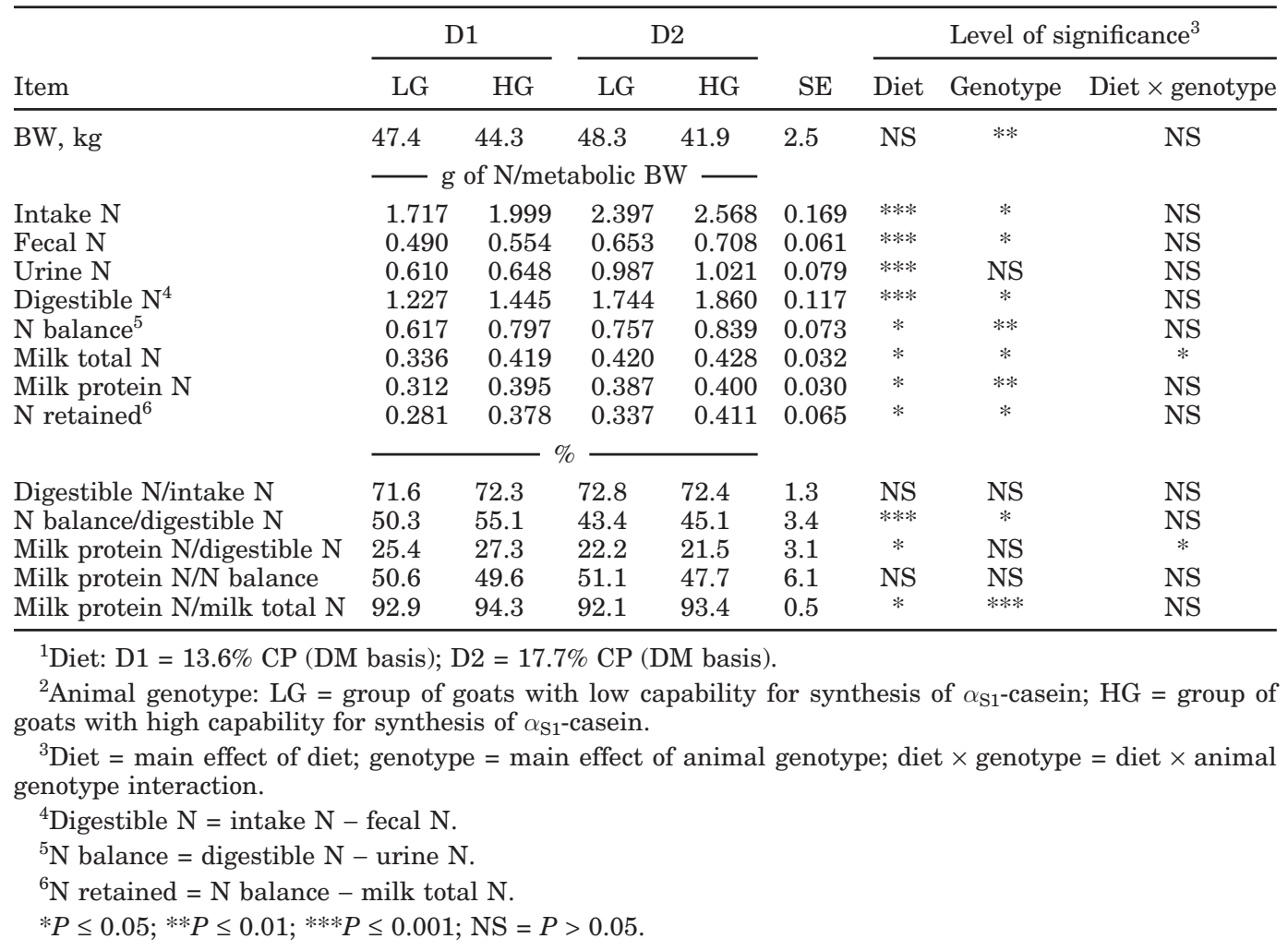

and acid detergent lignin (ADL) contents of the feedstuffs were determined (Van Soest et al., 1991), and fat content was determined after hydrochloric hydrolysis by extraction with petroleum ether (boiling point, 40 to $60^{\circ} \mathrm{C}$; Sanderson, 1986). The ash content was determined by incineration in an electric muffle furnace at $550^{\circ} \mathrm{C}$ and the energy content of the different samples by adiabatic bomb calorimetry. Apparent $\mathrm{N}$ digestibility and the $\mathrm{N}$ and energy balances were calculated from the corresponding feed intakes, fecal and urinary excretion, and milk output. Methane energy output was estimated according to Aguilera et al. (1990) as 9.09\% of digestible energy.

\section{Statistical Analysis}

Data were analyzed as a $2 \times 2$ factorial arrangement (Statgraphics, 2001); main effects were 2 diets and 2 genotypes in a completely randomized design. When the interaction term was not statistically significant $(P>$ 0.05 ), the least squares means were calculated from the model after this term was omitted (Steel and Torrie, 1980). The dependent variables in the model were $\mathrm{N}$ and energy intake data as well as the $\mathrm{N}$ and energy balance data. Duncan's multiple range test $(P<0.05)$ was used to determine the differences between the means.

\section{RESULTS}

Table 2 shows the results obtained for utilization of $\mathrm{N}$, by diet consumed and animal genotype, as well as the results of the statistical analysis. The dependent variables measured included $\mathrm{N}$ intake, fecal and urine $\mathrm{N}$ excretion, total $\mathrm{N}$ in milk and milk protein $\mathrm{N}$, digestible $\mathrm{N}$ ( $\mathrm{N}$ intake less fecal excretion), $\mathrm{N}$ balance (digested $\mathrm{N}$ less urine excretion), and $\mathrm{N}$ retained ( $\mathrm{N}$ balance less total milk N). All values are expressed as grams per MBW per day. To analyze the efficiencies with which $\mathrm{N}$ intake was utilized for digestion, metabolism, and milk production, the ratios indicative of such efficiencies were calculated. Diet affected $(P<0.05)$ values of $\mathrm{N}$ intake, fecal $\mathrm{N}$ excretion, urine loss of $\mathrm{N}$, digestible $\mathrm{N}, \mathrm{N}$ balance, total $\mathrm{N}$ in milk, protein $\mathrm{N}$ in milk, $\mathrm{N}$ retained, $\mathrm{N}$ balance/ digestible $\mathrm{N}$, milk protein $\mathrm{N} /$ digestible $\mathrm{N}$, and milk protein N/milk total N. Greater values were obtained for the goats in the $\mathrm{D} 2$ groups for $\mathrm{N}$ intake, fecal $\mathrm{N}$ excretion, urine loss of $\mathrm{N}$, digestible $\mathrm{N}, \mathrm{N}$ balance, total $\mathrm{N}$ in milk, protein $\mathrm{N}$ in milk, and $\mathrm{N}$ retained. However, lower values were obtained for the goats in the $\mathrm{D} 2$ groups, for $\mathrm{N}$ balance/digestible $\mathrm{N}$, milk protein $\mathrm{N} /$ digestible $\mathrm{N}$ and milk protein N/milk total N. Genotype affected $(P<0.05)$ values of $\mathrm{N}$ intake, fecal $\mathrm{N}$ excretion, digestible $\mathrm{N}, \mathrm{N}$ balance, total $\mathrm{N}$ in milk, protein $\mathrm{N}$ in milk, $\mathrm{N}$ retained, 
Table 3. Effect of type of $\operatorname{diet}^{1}$ and animal genotype ${ }^{2}$ on energy intake and excretion

\begin{tabular}{|c|c|c|c|c|c|c|c|c|}
\hline \multirow[b]{2}{*}{ Item } & \multicolumn{2}{|c|}{ D1 } & \multicolumn{2}{|c|}{ D2 } & \multirow[b]{2}{*}{$\mathrm{SE}$} & \multicolumn{3}{|c|}{ Level of significance ${ }^{3}$} \\
\hline & LG & $\mathrm{HG}$ & LG & HG & & Diet & Genotype & Diet $\times$ genotype \\
\hline & \multicolumn{8}{|c|}{ kJ/metabolic BW } \\
\hline Fecal energy & 410 & 480 & 463 & 480 & 34 & NS & * & NS \\
\hline Urine energy & 31 & 33 & 50 & 51 & 4 & $* * *$ & NS & NS \\
\hline Digestible energy $^{4}$ & 1,019 & 1,177 & 1,087 & 1,163 & 81 & NS & $*$ & NS \\
\hline Digestible energy/gross energy & 71.3 & 71.0 & 70.1 & 70.8 & 1.9 & NS & NS & NS \\
\hline Milk energy/digestible energy & 20.4 & 24.9 & 23.9 & 22.7 & 2.2 & NS & NS & $*$ \\
\hline Milk energy/ME & 23.2 & 28.2 & 27.7 & 26.2 & 2.5 & NS & NS & $*$ \\
\hline
\end{tabular}

${ }^{1}$ Diet: D1 = 13.6\% CP (DM basis); D2 = 17.7\% CP (DM basis).

${ }^{2}$ Animal genotype: LG = group of goats with low capability for synthesis of $\alpha_{\mathrm{S} 1 \text {-casein; } \mathrm{HG}}=$ group of goats with high capability for synthesis of $\alpha_{\mathrm{S} 1}$-casein.

${ }^{3}$ Diet $=$ main effect of diet; genotype $=$ main effect of animal genotype; diet $\times$ genotype $=$ diet $\times$ animal genotype interaction .

${ }^{4}$ Digestible energy = gross energy - fecal energy.

${ }^{5}$ Methane energy = methane output calculated from Aguilera et al. (1990) as 9.09\% of digestible energy.

${ }^{6} \mathrm{ME}=$ digestible energy - urine energy - methane energy.

$* P \leq 0.05 ; * * \leq 0.01 ; * * * \leq \leq 0.001 ; \mathrm{NS}=P>0.05$.

$\mathrm{N}$ balance/digestible $\mathrm{N}$, and milk protein $\mathrm{N} /$ milk total $\mathrm{N}$. All these values were greater for the HG goats. The interaction between factors for $\mathrm{N}$ balance $(P=0.10)$, milk total $\mathrm{N}(P=0.05)$, milk protein $\mathrm{N}(P=0.07)$ and $\mathrm{N}$ balance/digestible $\mathrm{N}(P=0.10)$ reveals that the effect of genotype was in these cases, more apparent when D1 was consumed. However, the interaction between factors for milk protein $\mathrm{N} /$ digestible $\mathrm{N}(P=0.05)$, indicates that the values for the HG goats were greater than those for the LG goats when D1 was consumed.

Total energy intake, fecal and urine energy excretion, losses as methane, the amount of digestible energy (DE, energy intake less fecal excretion), ME, and the energy in the milk (all expressed as kilojoules per MBW per day), and the energy efficiencies are given in Table 3. Diet affected $(P<0.05)$ urine energy losses, with greater losses for the goats in the D2 group. Genotype affected $(P<0.05)$ total energy intake, fecal losses, DE, $\mathrm{CH}_{4}$ losses, $\mathrm{ME}$, and energy in the milk, with greater values for the $\mathrm{HG}$ goats. The interactions between factors for energy in the milk, milk energy/DE, and milk energy/ $\mathrm{ME}$ was significant $(P<0.05)$. The values for the HG goats were greater than those for LG goats when the D1 diet was consumed.

\section{DISCUSSION}

\section{Utilization of Nitrogen}

Our data (Table 2) were very similar to those of Lindberg and Gonda (1996) who reported that, in lactating goats, the largest loss of the diet-derived intake of $\mathrm{N}$ is via urinary excretion (43\%), followed by fecal excretion (29\%) and the $\mathrm{N}$ in the milk produced (24\%). In our study, values for LG goats given the D1 diet were 43, 34 , and $23 \%$ for urinary $\mathrm{N}$ excretion, fecal $\mathrm{N}$ excretion, and $\mathrm{N}$ in the milk produced, respectively, whereas values in HG goats given the same diet were 40,34 , and $26 \%$, respectively. Values for LG goats given the $\mathrm{D} 2$ diet were 48,32 , and $20 \%$ for urinary $\mathrm{N}$ excretion, fecal N excretion, and $\mathrm{N}$ in the milk produced respectively, whereas those in HG goats given the same diet were 47, 33, and $20 \%$ for urinary $\mathrm{N}$ excretion, fecal $\mathrm{N}$ excretion, and $\mathrm{N}$ in the milk produced respectively.

As $\mathrm{N}$ intake increases, fecal N, urine $\mathrm{N}$, total $\mathrm{N}$ absorption, and milk $\mathrm{N}$ also increase (Badamana and Sutton, 1992; Kadzere and Jingura, 1993; Schmidely et al., 2002). Our data are similar. In agreement with Schmidely et al. (2002), we found that variations in the amounts of $\mathrm{N}$ retained in the body also increased in parallel with increasing levels of dietary protein; Badamana and Sutton (1992) reported different results. The utilization of protein or $\mathrm{N}$ in goats increases as the proportion of dietary protein increases, especially for diets with protein of low quality (Kadzere and Jingura, 1993; Swanson et al., 2000; Haddad et al., 2005). The efficiency with which the MP available is utilized for productive purposes is known to decrease as the levels of protein in the diet increase (Park, 1982). This has been confirmed in goats for growth (Sanz Sampelayo et al., 1995) and for milk production (Badamana and Sutton, 1992). 
Table 4. Changes in analyzed values for goats with low (LG) or high (HG) capability for synthesis of $\alpha_{\mathrm{S}^{-}}$ casein and fed D1 $\left(13.6 \% \mathrm{CP}\right.$ of DM) or D2 $(17.7 \% \mathrm{CP} \text { of DM})^{1}$

\begin{tabular}{|c|c|c|c|c|}
\hline \multirow[b]{2}{*}{ Item } & \multicolumn{2}{|c|}{$\begin{array}{l}\text { Difference between } \\
\text { genetic groups }^{2}\end{array}$} & \multicolumn{2}{|c|}{$\begin{array}{c}\text { Difference between } \\
\text { diets }^{3}\end{array}$} \\
\hline & D1 & D2 & LG & $\mathrm{HG}$ \\
\hline & & 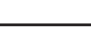 & . & 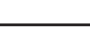 \\
\hline $\mathrm{N}$ balance & +29.2 & +10.8 & +22.7 & +5.3 \\
\hline Milk protein $\mathrm{N}$ & +26.6 & +3.4 & +24.0 & +1.3 \\
\hline Milk total $\mathrm{N}$ & +24.7 & +1.9 & +25.0 & +2.1 \\
\hline $\mathrm{N}$ balance/digestible $\mathrm{N}$ & +9.5 & +3.9 & -13.7 & -18.1 \\
\hline Milk protein N/digestible $\mathrm{N}$ & +7.5 & -3.2 & -12.6 & -21.2 \\
\hline Milk energy & +40.9 & +1.5 & +25.0 & -9.9 \\
\hline Milk energy/digestible energy & +22.1 & -5.0 & +17.2 & -8.8 \\
\hline Milk energy/ME & +21.6 & -5.4 & +19.4 & -7.1 \\
\hline
\end{tabular}

In this study, the efficiencies of using digestible $\mathrm{N}$ for $\mathrm{N}$ balance or for milk $\mathrm{N}$ were lower when $\mathrm{D} 2$ was consumed.

The greater $\mathrm{N}$ intake by the $\mathrm{HG}$ goats, irrespective of the level of protein in the diet, was the consequence of greater feed intake (Schmidely et al., 2002; De la Torre, 2006). In goats, energy intake is the principal factor determining the protein content of the milk produced (Morand-Fehr et al., 2000; Boza, 2005). Therefore, the greater capacity for feed intake should determine the greater capacity for milk production. Second, there was greater fecal $\mathrm{N}$ excretion as well as greater quantities of digestible $\mathrm{N}, \mathrm{N}$ balance, milk $\mathrm{N}$, and $\mathrm{N}$ retained within the body. However, urinary $\mathrm{N}$ excretion was unaffected. Despite the different levels of intake, this lack of effect of the genotype on urinary $\mathrm{N}$ loss should be considered of special interest, because it suggests that the HG goats achieved greater efficiency in the utilization of digestible $\mathrm{N}$ for milk production. The milk produced by HG goats had a greater proportion of protein $\mathrm{N}$ with respect to total $\mathrm{N}$, because of the lower quantity of NPN. The greater efficiency of HG goats in the utilization of MP for the production of milk protein depends on the protein content of the diet. This is an issue that requires more research. This is of vital practical interest, because it provides the foundation on which to modulate gene expression by means of nutrition.

The MP efficiencies for lactating goats reported herein are different than those reported for cows of diverse genetic types. McGilloway and Mayne (2002), studying cows of great genetic merit, reported that absorbed nutrients are apportioned more to milk production than to fat accretion. In the present study, although the HG goats were found to have lower average BW than the LG goats; the changes observed within each group between the start and end of the trials were less than \pm 0.60 $\mathrm{kg}$, which could simply be the result of differences in gut fill. Furthermore, the milk protein $\mathrm{N} / \mathrm{N}$ balance ratio was not affected $(P>0.05)$ by genotype.

The greater capacity for feed intake and the increased utilization of MP by HG goats compared with LG seems to explain why, under forced feeding conditions, the protein retention achieved is no greater than that resulting from ad libitum feeding conditions (McCrackens et al., 1994). The HG goats, in contrast to LG, possess a greater capacity for the utilization of MP, regulating their VFI in accordance with this greater capacity.

\section{Utilization of Energy}

It was not possible to determine $\mathrm{ME}$ intake in our study. When we consider a single class of animals consuming similar diets, the values of ME can be estimated on the basis of DE (Sanz Sampelayo et al., 2002). We found that MP was greater in HG goats, which suggests that the conversion of $\mathrm{DE}$ into ME must depend on the genotype. Metabolizable energy was estimated as being the difference between $\mathrm{DE}$ and the total energy losses as urine and methane. These latter values were estimated to be $9.09 \%$ of digestible energy (Aguilera et al., 1990). Gordon et al. (1995) reported that this loss does not vary between animals of diverse genotypes.

Despite the greater feed intake by HG goats, loss of energy via urine did not differ between genotypes within each diet. Goats with a high capacity for synthesis of AS1-CN are more energy efficient. The energy converted into milk as well as the efficiency with which DE or ME was utilized for milk production were greater for HG goats given the D1 diet. The HG goats are capable of producing milk with greater protein and fat contents (Barbieri et al., 1995).

There is little information available on the utilization of energy in the lactating goat by different genotypes. In 
dairy cattle of greater genetic merit, energy is apportioned in a greater proportion to the production of milk than to fat accretion (Gordon et al., 1995; Agnew et al., 2002); our results with Malagueña goats were similar.

\section{Implications}

The values consigned in Table 4 were derived from the values consigned in Tables 2 and 3. Compared with LG goats on the D1 diet, HG goats consuming D1 or LG goats consuming D2 had improved $\mathrm{N}$ balance, milk total $\mathrm{N}$, milk protein $\mathrm{N}$, milk energy, and greater efficiencies of utilization of $\mathrm{DE}$ or ME for milk production. The use of $\mathrm{HG}$ goats and changing from D1 to D2, or the use of the D2 diet and changing from LG to HG goats would be disadvantageous.

Greater VFI most affected the differences in the milk composition of dairy goats and the synthesis of AS1CN. Malagueña goats also presented a greater degree of metabolic utilization, both of $\mathrm{N}$ and energy consumed. There appears to be a nutrition $\times$ genotype interaction with regards to AS1-CN synthesis.

\section{ACKNOWLEDGMENTS}

This study was supported financially by the Ministry of Science and Technology, Spain (Project INIA: RTA02-020).

\section{REFERENCES}

Agnew, R. E., T. Yan, and F. J. Gordon. 2002. Nutrition of the high genetic merit dairy cow. Energy metabolism studies. Pages 255282 in Recent Developments in Ruminant Nutrition. Vol. 4. J. Wiseman and P.C. Garnsworthy, ed. Nottingham University Press, Nottingham, UK

Aguilera, J. F., C. Prieto, and J. Fonollá. 1990. Protein and energy metabolism of lactating Granadina goats. Br. J. Nutr. 63:165-175.

Amills, M. 1996. Diseño y aplicación de técnicas moleculares para el análisis del efecto del polimorfismo de la caseína $\alpha_{\mathrm{S} 1}$ caprina sobre caracteres productivos. $\mathrm{PhD}$ thesis. Autonomous University of Barcelona, Spain.

AOAC. 2005. Official Methods of Analysis. 18th ed. Association of Official Analytical Chemists, Gaithersburg, MD.

Badamana, M. S., and J. D. Sutton. 1992. Hay intake, milk production and rumen fermentation in British Saanen goats given concentrates varying widely in protein concentration. Anim. Prod. 54:395-403.

Barbieri, M. E., F. Manfredi, J. M. Elsen, G. Ricordeau, J. Bouillon, and F. Grosclaude. 1995. Influence du locus de la caséine $\alpha_{\mathrm{S} 1}$ sur les performances laitières et les paramètres génétiques de chèvres de race Alpine. Genet. Sel. Evol. 27:437-450.

Boulanger, A., F. Grosclaude, and M. F. Mahé. 1984. Polymorphisme des caséines $\alpha-1$ et $\alpha$-s2 de la chévre. Genet. Sel. Evol. 16:157-175.

Boza, J. 2005. Alimentación de la cabra en lactación. In High Course of Animal Production. International Centre of High Mediterranean Agronomic Studies, Zaragoza, Spain.

De la Torre, M. G. 2006. Interacción entre el gen de la $\alpha_{\mathrm{S} 1}$-caseína y el nivel de proteína de la dieta. Utilización nutritiva, producción y composición de la leche en cabras de raza Malagueña. $\mathrm{PhD}$ thesis. University of Granada, Spain.

Gordon, F. J., M. G. Porter, C. S. Mayne, E. F. Unsworth, and D. J. Kilpatrick. 1995. Effect of forage digestibility and type of concen- trate on nutrient utilization by lactating dairy cattle. J. Dairy Res. 62:15-27.

Grosclaude, F., M. F. Mahé, G. Brignon, L. Di Stasio, and R. Jeunet. 1987. A Mendelian polymorphism underlying quantitative variation of goat $\alpha_{\mathrm{S} 1}$-casein. Genet. Sel. Evol. 19:399-412.

Haddad, S. G., K. Z. Mahmoud, and M. A. Talfaha. 2005. Effect of varying levels of dietary undegradable protein on nutrient intake, digestibility and growth performance of Awasi lambs fed on high wheat straw diets. Small Rumin. Res. 58:231-236.

Kadzere, C. T., and R. Jingura. 1993. Digestibility and nitrogen balance in goats given different levels of crushed whole soybeans. Small Rumin. Res. 10:175-180.

Lindberg, J. E., and H. L. Gonda. 1996. Fiber and protein digestion in goats. Pages 495-509 in Proc. 6th Int. Conf. Goats. Vol. 2. Int. Acad. Publ., Beijing, China.

McCrackens, K. J., J. McEvoy, A. McAllister, J. Lilley, and R. Urquhart 1994. Effects of overfeeding on protein/energy metabolism and body composition of high genetic potential bears. Pages 217-220 in Proc. 13th Symp. Energy Metabolism, EAAP Publication 46 Consejo Superior de Investigaciones Científicas, Madrid, Spain.

McGilloway, D. A., and C. S. Mayne. 2002. The importance of grass availability for the high genetic merit dairy cow. Pages 13-45 in Recent Developments in Ruminant Nutrition. Vol. 4. J. Wiseman and P. C. Garnsworthy, ed. Nottingham University Press, Nottingham, UK.

Morand-Fehr, P., M. R. Sanz Sampelayo, Y. V. Fedele, Y. Le Frileux, and M. Eknaes. Ph. Schmidely, S. Giger-Reverdin, P. Bas, R. Rubino, $\varnothing$. Havrevall, and D. Sauvant. 2000. Effect of feeding on the quality of goat milk and cheese. Pages 53-65 in Proc. 7 Int. Conf. Goat. Vol. 1. Tours, France. Int. Goat Assoc.

NRC. 2007. Pages 271-280 in Nutrient Requirements of Small Ruminants. Natl. Academic Press, Washington, DC.

Park, J. R. 1982. Introduction. Pages 1-24 in A Theory of Feeding and Growth of Animals. D. F. R. Bommer, B. R. Sabey, G. W. Thomas, Y. Vaadia and L. D. Van Vleck, ed. Springer Verlag, Berlin, Germany.

Sacchi, P., S. Chessa, E. Budelli, P. Bolla, G. Ceriotti, D. Soglia, R. Rasero, E. Cauvin, and A. Caroli. 2005. Casein haplotypes in five Italian goat breeds. J. Dairy Sci. 88:1561-1568.

Sanderson, P. 1986. A new method of analysis of feedingstuffs for the determination of crude oils and fats. Pages 77-81 in Recent Advances in Animal Nutrition. W. Haresign and D. J. A. Cole, ed. Butterworths, London, UK.

Sanz Sampelayo, M. R., L. Allegretti, I. Ruiz Mariscal, F. Gil Extremera, and J. Boza. 1995. Dietary factors affecting the maximum feed intake and the body composition of pre-ruminant kid goats of the Granadina breed. Br. J. Nutr. 74:335-345.

Sanz Sampelayo, M. R., L. Pérez, J. J. Martín Alonso, F. Gil Extremera, and J. Boza. 2002. Effects of concentrates with different contents of protected fat rich in PUFAs on the performance of lactating Granadina goats. 1. Feed intake, nutrient digestibility, $\mathrm{N}$ and energy utilisation for milk production. Small Rumin. Res. 43:133139.

Schmidely, Ph., F. Meschy, J. Tessier, and D. Sauvant. 2002. Lactation response and nitrogen, calcium and phosphorus utilization of dairy goats differing by the genotype for $\alpha_{\mathrm{S} 1}$-casein in milk, and fed diets varying in crude protein concentration. J. Dairy Sci. 85:2299-2307.

Serradilla, J. M. 2002. The goat $\alpha \mathrm{s} 1$ casein gene: A paradigm of the use of a major gene to improve milk quality? Cah. Options Méditerr. 57:99-106.

Statgraphics. 2001. User manual: Statistical Graphics System by Statistical Graphics Corporation. Statgraphics, Herndon, VA.

Steel, R. G. D., and J. H. Torrie. 1980. Principles and Procedures of Statistics: A Biometrical Approach. Pages 336-343 in 2nd ed. McGraw-Hill Book Co., New York, NY.

Swanson, K. C., J. S. Caton, D. A. Redmer, V. I. Burke, and L. P. Reynolds. 2000. Influence of undegraded intake protein on intake, digestion, serum hormones and metabolites and nitrogen balance in sheep. Small Rumin. Res. 35:225-233.

Van Soest, P. J., J. B. Robertson, and B. A. Lewis. 1991. Methods for dietary fiber, detergent fiber and non-starch polysaccharides in relation to animal nutrition. J. Dairy Sci. 74:3583-3597. 